\title{
AGROBIOLOGICAL VALUE OF SOME WHITE GRAPE VARIETIES CREATED AT RESEARCH AND DEVELOPMENT STATION FOR VITICULTURE AND VINIFICATION ODOBEȘTI, VRANCEA COUNTY, ROMANIA
}

\author{
Ionica BOSOI ${ }^{1, *}$, Liliana ROTARU', \\ Cintia COLIBABA', Marioara PUȘCALĂU ${ }^{2}$ \\ *E-mail: oana_boss2002@yahoo.com
}

Received: Dec. 10, 2021. Revised: Jan, 26, 2022,. Accepted: Jan, 30, 2022. Published online: Feb. 2, 2022

\begin{abstract}
Vine varieties react differently to the influence of environmental factors by decreasing or significantly intensifying the vigour of shoot growth, a biological reaction that also affects fertility and productivity. This article presents data on some agrobiological properties (vegetative growth of shoots, fertility and productivity) of some white wine varieties, created at the Research and Development Station for Viticulture and Vinification (R.D.S.V.V.) Odobești, Vrancea County, Romania) - Şarba, Băbească gri, Mioriţa and Vrancea, in the period 2020 2021. The data obtained were compared with the control variety Fetească regală. In Odobeşti vineyard, 2020 was much warmer than normal, characterized by a severely deficient rainfall regime resulting in atmospheric drought, followed by the gradual development of pedological drought. The vigour of shoots was negatively influenced by the climatic conditions of the vegetation period in 2020, the highest values being recorded for the varieties Sarba $(159.6 \mathrm{~cm})$ and Vrancea $(141.5 \mathrm{~cm})$, which showed significant positive differences, compared to the control variety. The fertility of the buds
\end{abstract}

was lower in 2020 , compared to 2021 , the Vrancea variety being distinguished by higher potential fertility than the varieties Șarba, Băbească gri and Miorița, but lower potential fertility than the control variety. The absolute fertility coefficient (Cfa) had superunitary values for all varieties (1.07 - 1.50), and the relative fertility coefficient (Cfr) had subunitary values, except for the Vrancea variety (1.32). The varieties Șarba, Băbească gri and Miorița achieved an absolute productivity index (Ipa) superior to the control variety Fetească regală due to the higher average weight of the grapes, and the relative productivity index (Ipr) ranged from 199 for the Vrancea variety to 182 for the variety Șarba.

Keywords: grape variety; vigour; fertility coefficients; productivity index.

\section{INTRODUCTION}

The genetic characteristics of the variety (inherited genotype or genetic behavior), the environmental conditions and the genotype-environment interaction

\footnotetext{
1 University of Life Sciences „Ion lonescu de la Brad” lasi, Romania

${ }^{2}$ Research and Development Station for Viticulture and Vinification Odobești, Vrancea County, Romania
} 


\section{Ionica BOSOI, Liliana ROTARU, Cintia COLIBABA, Marioara PUȘCALĂU}

decisively influence the productivity, quality and adaptability of the vine varieties (Costa et al., 2015; Marangon and Kallithraka, 2021; Omazic et al., 2020; Rodrigues et al., 2019; Sestraș, 2004). The continuous enrichment of the viticultural assortment through the introduction of some newly created varieties is an important means of quantitatively and qualitatively increasing the production of grapes and wine (Popescu et al., 1976, 1973). Given the fact that the Odobeşti vineyard is considered a wine-growing area with a vocation for white wines, the creation of new varieties for this area is essential to expand the varietal assortment.

The aim of this research was to evaluate the agrobiological value of some white grape varieties created at R.D.S.V.V. Odobești, in order to highlight the most valuable, i.e., those with superior productive and qualitative potential to those existing in culture, and adapted to the constantly changing climatic conditions (Mihu et al., 2016; Pușcalău et al., 2017; Bosoi et al., 2020).

\section{MATERIALS AND METHODS}

Four grape varieties used to produce white wines and created at R.D.S.V.V. Odobeşti were studied: Şarba (approved in 1972), Băbească gri (approved in 1975), Mioriţa (approved in 1980) and Vrancea (approved in 2018). The varieties were obtained by sexual and asexual hybridization, as follows: Şarba (Italian Riesling - free pollination); Băbească gri (Băbească neagră - genetic mutation); Miorița (Coarnă albă - free pollination), Vrancea - (Traminer $\times$ Armaș $\times$ Fetească regală). The scientific investigations were carried out in a 10-year-old vineyard, established on a cambic chernozem within the R.D.S.V.V. Odobeşti, with the geographical coordinates $45^{\circ} 45^{\prime \prime}$ north lat., $27^{\circ} 06^{\prime \prime}$ east long., and an altitude of $150 \mathrm{~m}$.

The varieties studied were grafted onto the rootstock Berlandieri $\times$ Riparia Selection Oppenheim 4, clone 4 . The pruning system practiced was the Dr. Guyot system, with a fruit load between 38 - 44 buds/vine, distributed on 8 - 9 buds per fruiting cane with two buds per spur, and a semi-high driving shape. The support system consisted of trellis with double wire on three levels. The planting distance was $2.2 \mathrm{~m} \times 1.2 \mathrm{~m}$, resulting in 3787 vine/ha. The soil was maintained on bare fallow, with autumn fertilization and chemical fertilizers based on phosphorus, potassium and trace elements, non-irrigated. Eight phytosanitary treatments were applied to control the pathogens (Plasmopara viticola, Uncinula necator, Botrytis cinerea, etc),

Each variant (genotype) was represented in this study by three repetitions with five vine each. In order to evaluate the agrobiological value of the varieties included in the study, measurements of vegetative growth were made by measuring three shoots/trunk (large, medium and small) in the period of intense growth and aspects of fertility and productivity were measured by calculating the percentage of fertile shoots (FS\%), fertility coefficients ( $\mathrm{Cfa}$ and Cfr) and productivity indices (Ipa and Ipr) by the following formulas:

$$
\begin{aligned}
\mathrm{FS} \% & =\frac{\text { Fertile shoots }}{\text { Total shoots }} \times 100 ; \\
\mathrm{Cfa} & =\frac{\text { No. inflorescence }}{\text { Fertile shoots }} \geq 1 ; \\
\mathrm{Cfr} & =\frac{\text { No. inflorescence }}{\text { Total shoots }} ; \\
\mathrm{Ipa} & =\mathrm{Cfa} \times \mathrm{g} ; \quad \mathrm{lpr}=\mathrm{Cfr} \times \mathrm{g},
\end{aligned}
$$

$\mathrm{g}=$ average grape weight at full maturity

The climatic data of the study period were provided by the AgroExpert weather station and the multiannual climatic database 
of R.D.S.V.V. Odobeşti. The useful thermal balance $\left(\Sigma^{\mathrm{o}} \mathrm{tu}\right)$ represents the sum of the differences between the average daily temperature $>10^{\circ} \mathrm{C}$ and the biological starting threshold in vegetation of the vine $\left(10^{\circ} \mathrm{C}\right)$.

\section{RESULTS AND DISCUSSION}

\section{Climate conditions}

The thermal regime of the vegetation period was excessive in 2020, characterized by an average air temperature of $19.7^{\circ} \mathrm{C}$ (Table 1), well above the multiannual average $\left(18.2^{\circ} \mathrm{C}\right)$, and normal in $2021\left(18.3^{\circ} \mathrm{C}\right)$. The useful thermal balance $\left(\Sigma^{\circ}\right.$ tu $)$ and the amount of heatstroke during the vegetation period in 2020 were well above the multiannual value. The precipitation regime during the vegetation period was severely deficient in 2020 (215.0 mm), compared to the multiannual average $(416.0 \mathrm{~mm})$, and the number of days with maximum temperatures $>30^{\circ} \mathrm{C}$ was 67 , compared to the norm of 48 days, leading to pedological and atmospheric drought.

\section{Vegetative growth of shoots}

The climatic conditions in 2020 were less favourable, negatively influencing the physiological and metabolic processes that condition the growth and development of shoots. Analysis of shoots length in 2020 showed smaller increases within varieties by $22-36 \mathrm{~cm}$, compared to 2021, a year with values of climatic parameters close to multiannual values (Table 2). Depending on the total number of shoots per trunk (30.2 - 42.6), increases in shoot length were normal in 2021, with a correlation between the total number of shoots/trunk and the minimum, maximum or average length of shoots.

According to the analysis of the growth of shoots during the vegetation period (2020 - 2021), the highest growth was recorded for the variety Sarba with an average length of the main shoots of $159.6 \mathrm{~cm} / \mathrm{shoot}$, followed by the variety Vrancea with $141.5 \mathrm{~cm} / \mathrm{shoot}$, these varieties registering very significant positive differences, compared to the control variety Fetească regală (Table 3). The Băbească gri variety registered a significantly positive difference, compared to the control, while for the Miorița variety the average length of the main shoots was $120.5 \mathrm{~cm} / \mathrm{shoot}$, a value close to that of the control variety. These values correspond to a degree of vegetative development capable of sustaining a balance between growth and fruiting, the optimum being when the shoots have an average length of $1.0-1.5 \mathrm{~m}$.

Table 1 - The climatic conditions during the growing season (Odobeşti, 2020 - 2021)

\begin{tabular}{lccc}
\hline \multicolumn{1}{c}{ Climate indicator } & $\begin{array}{c}\text { Multiannual } \\
(\mathbf{1 9 7 0}-\mathbf{2 0 1 9 )})\end{array}$ & $\mathbf{2 0 2 0}$ & $\mathbf{2 0 2 1}$ \\
\hline \multicolumn{1}{c}{ In the vegetation period } & & \\
\hline Medium temperature ${ }^{\circ} \mathrm{C}$ & 18.2 & 19.7 & 18.3 \\
\hline Absolute maximum temperature, ${ }^{\circ} \mathrm{C}$ & 39.4 & 37.0 & 37.1 \\
\hline Absolute minimum temperature, ${ }^{\circ} \mathrm{C}$ & -3.5 & -0.6 & -1.3 \\
\hline Amount degrees useful temp $\left(\Sigma^{\circ} \mathrm{tu}\right),{ }^{\circ} \mathrm{C}$ & 1552.3 & 1793.4 & 1566.7 \\
\hline The amount of heatstroke, hours & 1509.9 & 1725.0 & 1597.5 \\
\hline Precipitation amount, mm & 416.0 & 215.0 & 289.6 \\
\hline Number of days with maximum $\mathrm{t}>30^{\circ} \mathrm{C}$ & 48 & 67 & 46 \\
\hline
\end{tabular}


Table 2 - Length of vegetative growth

\begin{tabular}{cccccccccc}
\hline \multirow{2}{*}{ Variety } & \multicolumn{3}{c}{ Total shoots / vine } & \multicolumn{5}{c}{ Shoot length, cm } \\
\cline { 2 - 10 } & $\mathbf{2 0 2 0}$ & $\mathbf{2 0 2 1}$ & average & $\mathbf{2 0 2 0}$ & $\mathbf{2 0 2 1}$ & average & $\mathbf{2 0 2 0}$ & $\mathbf{2 0 2 1}$ & average \\
\hline Şarba & 35.8 & 30.2 & 33.0 & 67.5 & 80.6 & 74.1 & 206.2 & 283.9 & 245.0 \\
\hline Băbească gri & 36.5 & 38.6 & 37.6 & 43.7 & 45.6 & 44.7 & 171.0 & 235.4 & 203.2 \\
\hline Mioriţa & 39.6 & 34.5 & 37.1 & 47.0 & 55.3 & 51.2 & 165.4 & 214.1 & 189.8 \\
\hline Vrancea & 30.8 & 42.6 & 36.7 & 45.3 & 46.9 & 46.1 & 215.2 & 258.6 & 236.9 \\
\hline $\begin{array}{c}\text { Fetească } \\
\text { Regală (control) }\end{array}$ & 33.8 & 39.4 & 36.6 & 40.5 & 43.5 & 42.0 & 167.4 & 218.3 & 192.9 \\
\hline
\end{tabular}

Table 3 - Average shoot length

\begin{tabular}{|c|c|c|c|c|}
\hline \multirow[b]{2}{*}{ Variety } & \multicolumn{4}{|c|}{ Average shoot length } \\
\hline & $\begin{array}{c}\text { Average } 2020-2021 \\
(\mathrm{~cm})\end{array}$ & $\%$ & $\begin{array}{c}\text { Difference } \\
(+/-\mathrm{cm})\end{array}$ & Significance \\
\hline Şarba & 159.57 & 135.89 & 42.14 & $* * *$ \\
\hline Băbească gri & 123.93 & 105.54 & 6.50 & * \\
\hline Mioriţa & 120.47 & 102.59 & 3.04 & - \\
\hline Vrancea & 141.53 & 120.52 & 24.10 & $* * *$ \\
\hline Fetească regală & 117.43 & 100.00 & 0.00 & - \\
\hline DL 5\% & & & 5.54 & \\
\hline DL $1 \%$ & & & 7.77 & \\
\hline DL $0,1 \%$ & & & 10.97 & \\
\hline
\end{tabular}

\section{Fertility and productivity.}

The fertility and productivity parameters of the vine varieties were evaluated by the percentage of fertile shoots (FS\%), the number of inflorescences / vines, the fertility coefficients (absolute and relative) and productivity indices (absolute and relative) and are shown in Table 4 and Table 5. The proportion of fertile shoots in the total number of shoots on a trunk is one of the most important indicators for assessing the real fertility of a variety.

During the studied period (2020 2021) the percentage of fertile shoots was variable within the same genotype, but within the typical range for each variety. This variability was due to the specific climatic conditions of 2020, when under the influence of prolonged drought in similar growing conditions and with relatively close fruit set, the proportion of fertile shoots was below the level of the known biological potential of the varieties. The lowest percentage of fertile shoots was recorded in the Sarba variety at $60.7 \%$, and the highest in the Vrancea variety at $83.8 \%$ fertile shoots. In the Miorița and Băbească gri varieties the percentage of fertile shoots was $61.5 \%$ and $62.1 \%$, respectively.

These values were lower than that of the control variety Fetească regală (91.9\% fertile shoots), which is known as a variety with very good fertility. In 2021, considered normal from the climatic point of view, fertility varied between varieties, the Vrancea variety being notable with $92.5 \%$ fertile shoots. 


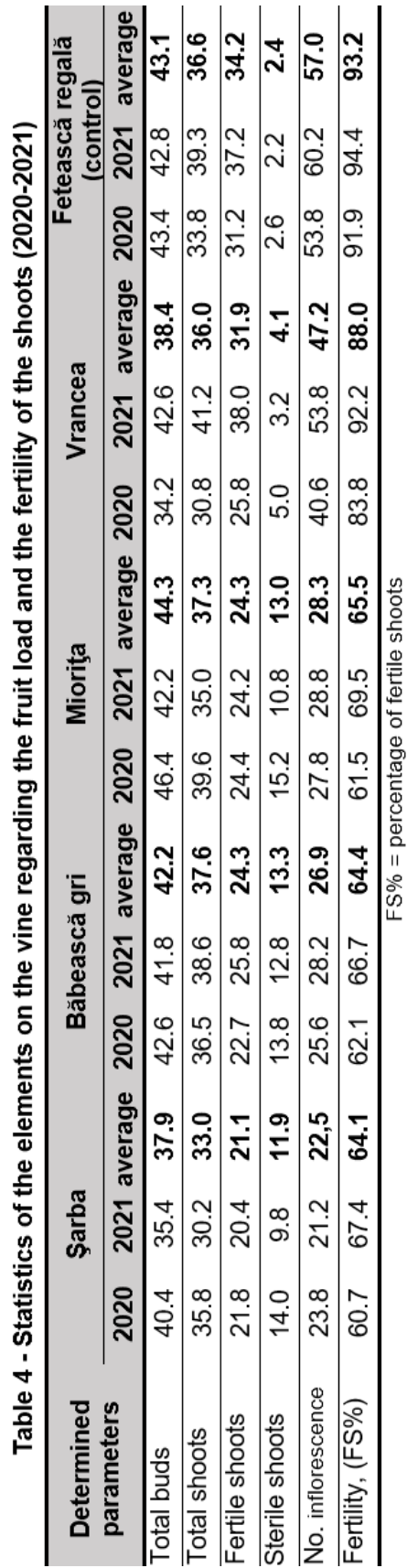

The number of inflorescences that form on the trunk is a genetic trait, influenced by climatic conditions, fruit load assigned to pruning, etc. In the

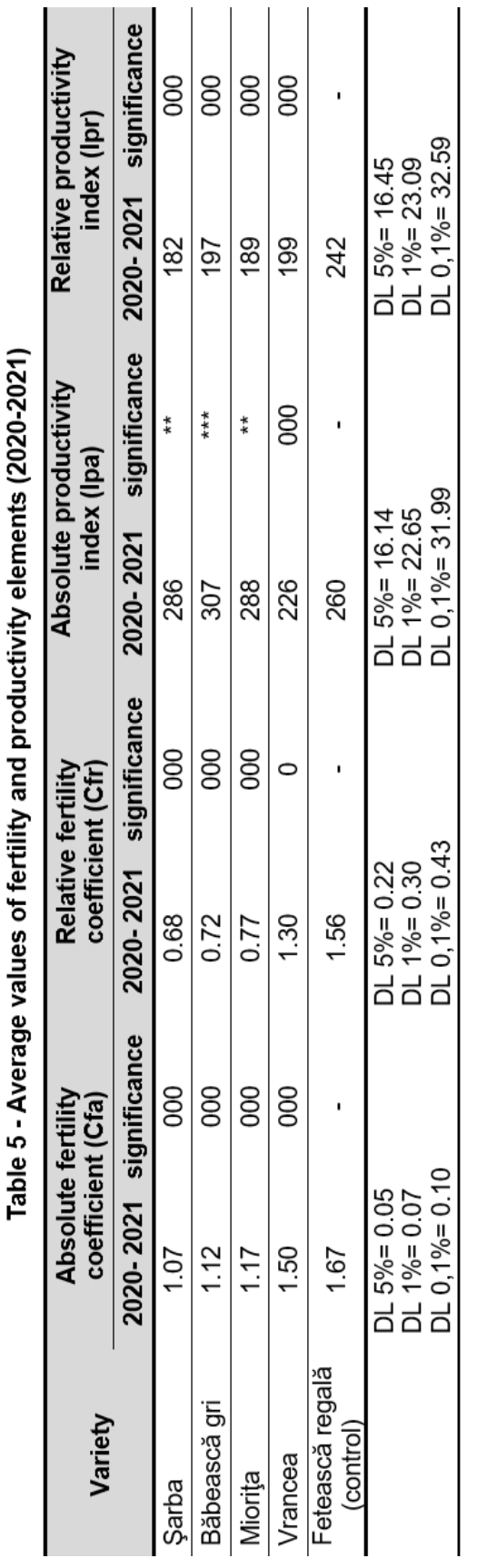

study carried out, the average number of inflorescences/vine stock varied between 22.5 for the Șarba variety and 47.4 for the recently created Vrancea variety, 


\section{Ionica BOSOI, Liliana ROTARU, Cintia COLIBABA, Marioara PUȘCALĂU}

values below that of the control variety Fetească regală (57.0). The varieties Mioriţa and Băbească gri had an average number of inflorescences/vine of 28.3, and 26.9 , respectively, being also below the value of the control variety.

\section{Fertility coefficients}

The absolute fertility coefficient (Cfa) expresses the ratio between the number of inflorescences on the vine and the number of fertile shoots on the same vine. In the study years 2020 2021, the lowest absolute fertility coefficient was recorded in the Şarba variety with an average value of 1.07 , and the highest $\mathrm{Cfa}$ was recorded in the Vrancea variety with an average value of 1.50 (Fig. 1).

The average value of $\mathrm{Cfa}$ for the Miorița and Băbească gri varieties was 1.12 and 1.17 , respectively. The values in all four genotypes studied were significantly lower, compared to the control variety.

The relative fertility coefficient (Cfr), which expresses the ratio between the number of inflorescences on the vine and the total number of shoots on the same vine, was subunitary for the varieties Șarba (0.66 - 0.70), Băbească gri $(0.70-0.72)$, and Mioriţa (0.70 0.83 ), and supraunitary for the Vrancea variety, with values between 1.31 and 1.33 (Fig. 2).

In the case of the relative fertility coefficient, the values were below those of the control variety Fetească regală $(1.58$ - 1.53), the differences being significantly lower for the Vrancea variety and very significantly lower for the Băbească gri, Miorița and Șarba varieties.

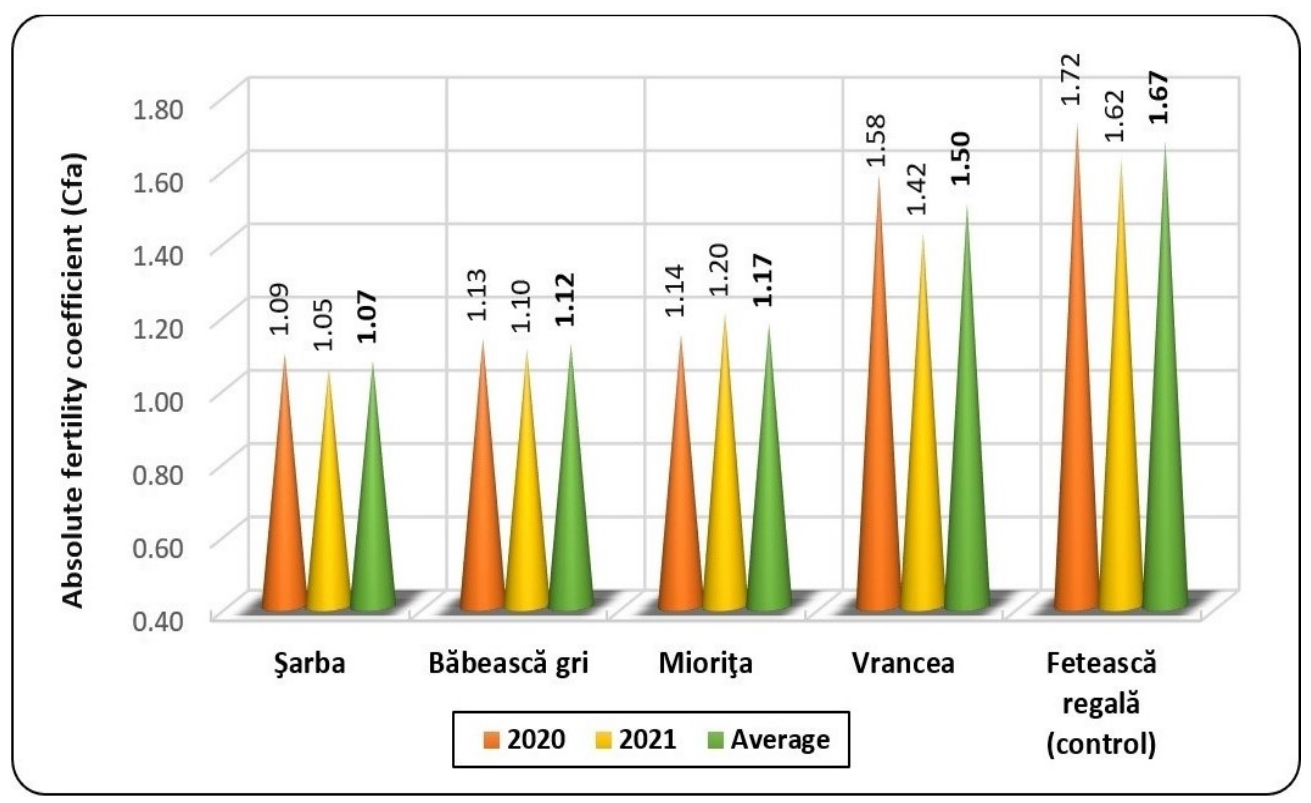

Figure 1 - Absolute fertility coefficient of the varieties studied (2020 - 2021) 


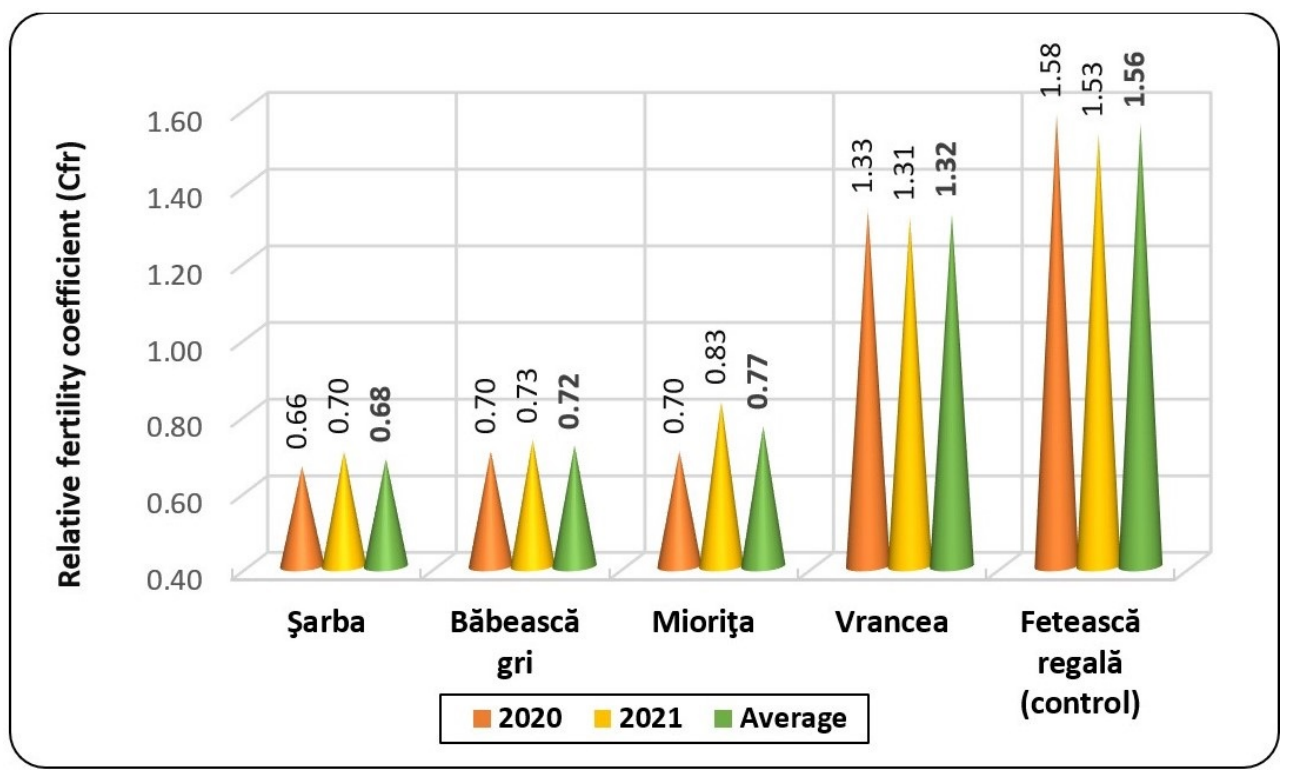

Figure 2 - Relative fertility coefficient of the varieties studied (2020 - 2021)

\section{Productivity indices}

The absolute productivity index (Ipa) is the weight in grams of grape production on each fertile shoot on the vine. In the two years of study (2020 and 2021), the absolute productivity index was higher in the varieties Băbească gri, Şarba and Miorița, compared to the Vrancea variety, due to the higher average weight of the grapes. In the climatic conditions of 2020, the Băbească gri variety was notable, with an Ipa value of 303, whereas in 2021 the Miorița variety was notable, with an Ipa value of 316 (Fig. 3). These varieties showed very significant positive differences from the control variety. Significant positive differences, compared to the control variety, were also observed in the Șarba variety, in which the average value of the absolute fertility index was 286.3. For the Vrancea variety, the average value of this index was 226.1 , being significantly lower compared to the control variety Fetească regală. The relative productivity index (Ipa) is the weight in grams of grape production on each shoot on the vine (fertile and sterile).

The relative productivity index (Ipr) in 2020 varied between 159 for the Miorița variety and 196 for the Vrancea variety, and in 2021 was higher, with values between 197 for the Șarba variety and 219 for the Miorița variety (Fig. 4). The average values of Ipr for the four genotypes analysed were significantly lower compared to the control variety Fetească regală.

The results regarding the fruiting capacity of the studied varieties show that the known biological potential has been reached. The small differences between the repetitions of the same variety allow the appreciation that they have acquired genetic stability and present a good adaptability to the climatic and edaphic conditions in the area. 
Ionica BOSOI, Liliana ROTARU, Cintia COLIBABA, Marioara PUȘCALĂU

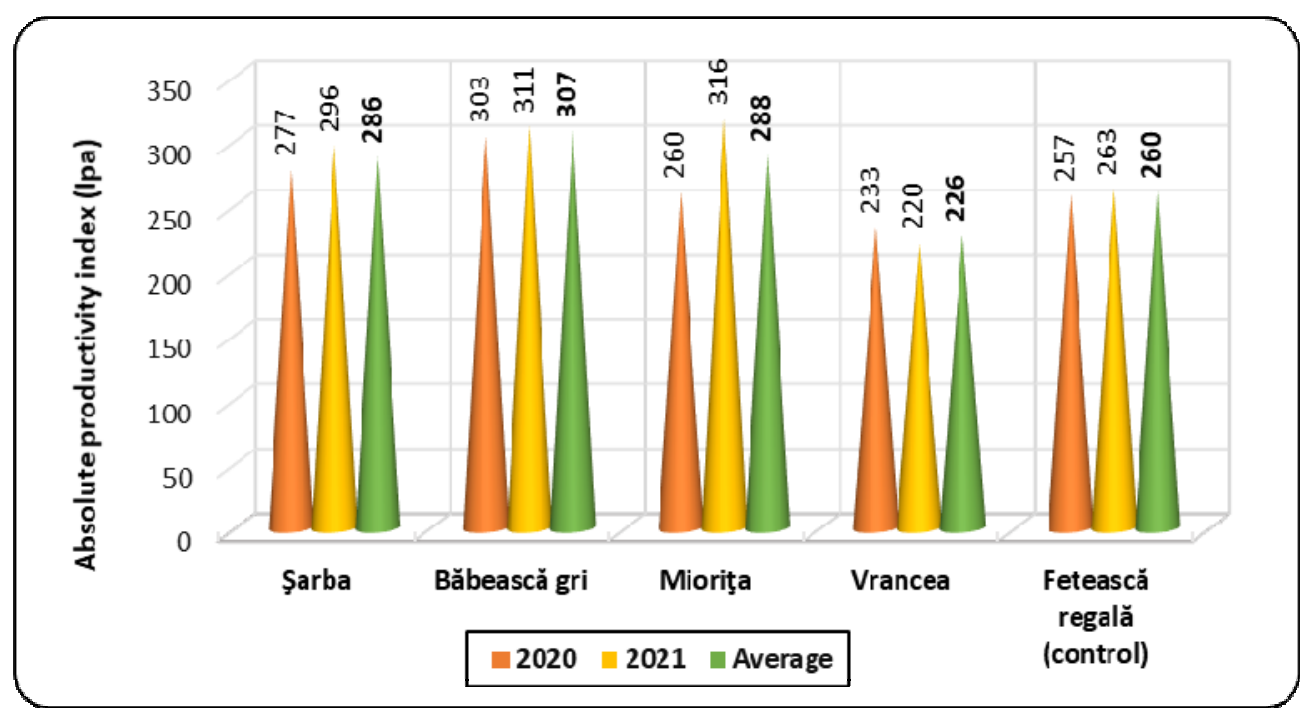

Figure 3 - Absolute productivity index of the studied varieties $(2020-2021)$

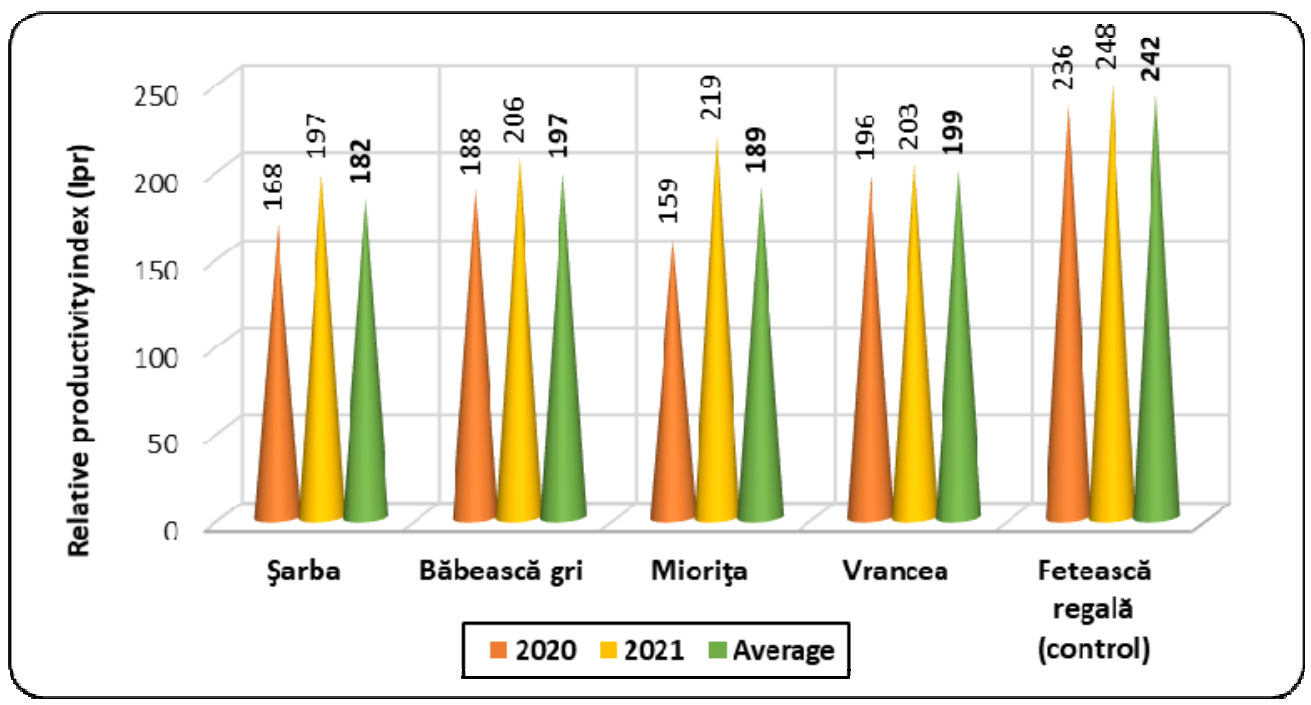

Figure 4 - Relative productivity index of the studied varieties $(2020-2021)$

\section{CONCLUSIONS}

The values of the main climatic parameters during the vegetation period varied significantly during the 2 years of study, with 2021 having values close to the multiannual average, while 2020 was extremely dry. The growth vigour of the shoots was negatively influenced by the climatic conditions of the vegetation period in 2020, with the varieties Șarba and Vrancea showing significantly positive differences compared to the control variety.

The studied varieties showed higher potential fertility in 2021, compared to 


\section{AGROBIOLOGICAL VALUE OF SOME WHITE GRAPE VARIETIES CREATED AT R.D.S.V.V. ODOBEȘTI}

2020. The Vrancea variety was distinguished by a higher fertility potential than the Şarba, Băbească gri and Miorița varieties, but lower than the control variety. Due to the higher average weight of the grapes, the varieties Șarba, Băbească gri and Miorița achieved an absolute productivity index (Ipa) superior to the the control variety Fetească regală.

\section{REFERENCES}

Bosoi, I., Rotaru, L. \& Puşcalău, M. (2020) - Vrancea - new variety of vine for obtaining white wine of higher quality created at S.C.D.V.V. Odobești. Scientific Papers. Series B, Horticulture. Vol. LXIV, No. 2, 133-137, Bucharest.

Costa, E., da Silva, J.F., Cosme, Fernanda \& Jordão, A.M. (2015). Adaptability of some French red grape varieties cultivated at two different Portuguese terroirs: Comparative analysis with two Portuguese red grape varieties using physicochemical and phenolic parameters. Food Res. Int., 78: 302312. DOI: 10.1016/j.foodres.2015.09. 029

Marangon, M. \& Kallithraka, Stamatina (2021). Improving wine quality and safety. 2021. Beverages, 7(2): 19, DOI: $.3390 /$ beverages 7020019

Mihu, G. et al. (2016). New varieties and clones for wine and table grapes obtained at S.C.D.V.V. Odobeşti, Anale I.C.-D.V.V. Valea Călugarească, Bucharest.

Omazic, B., Prtenjak, M.T., Prša, I., Vozila, A.B., Vučetić, V., Karoglan, M., Kontić, J.K., Prša, Z., Anić, M.,
Šimon, S. \& Guttler I. (2020). Climate change impacts on viticulture in Croatia: Viticultural zoning and future potential. Int. J. Climatol., 40(13): 56345655, DOI: 10.1002/joc.6541

Popescu, Gh., Bădițescu Margareta \& Popescu, T. (1973). The natural mutant Băbească gri, a kind of perspective for the Odobești vineyard (in Romanian). Anale I.C.-D.V.V. Valea Călugărească, Vol. V, 69-80, Bucharest.

Popescu, Gh., Bădiţescu, M, Petrescu, M., Popa, A., Constantinescu, S., Taras, S., Gherghe, V. \& Baractaru, M. (1976). New varieties for recently approved wine grapes (in Romanian), Anale I.C-D.V.V. Valea Călugărească, Vol. VII, 55-63, Bucharest.

Popescu, T., Constantinescu, S. \& Varga, M. (1983). Research on the production of semi-aromatic wine from the Sarba variety (in Romanian), Anale I.C.-D.V.V. Valea Călugărească, Vol. X, 421-430, Bucharest.

Puşcalău, M., Bosoi, I. \& Mihu, G. (2017). Evaluation of the agrobiological and technological potential of some hybrid elites obtained at R.D.S.V.V. Odobeşti, in order to homologate and improve the national assortment in the context of sustainable viticulture (in Romanian). Revista Hortus, Agricola Publishing House, 15: 280-285.

Rodrigues, R.F.C., Lima, A., Melo, A.C.F.L. \& Trindade, R.A. (2019). Physicochemical characterisation, bioactive compounds and in vitro antioxidant activities of commercial integral grape juices. Int. Food Res., 26(2): 469-479.

Sestraş, R. (2004). Improvement of horticultural species, Cluj-Napoca, RO: AcademicPres Publishing House. 